Izet Ibrahimi ${ }^{1}$, orcid.org/0000-0002-8858-0462,

Nurten Deva ${ }^{1}$, orcid.org/0000-0003-4883-8024,

Skender Muqolli ${ }^{2}$, orcid.org/0000-0001-9691-0823
1 - University Isa Boletini, Mitrovice, Kosovo, email:

nurten.deva@umib.net

2 - Laboratori ,AHN Group”, Prishtinë, Kosovo

\title{
INTEGRATED DRY GRANULATION - POSSIBILITY OF REDUCING ENVIRONMENTAL POLLUTION AND VALORIZATION OF FE-NI SLAG
}

Purpose. The aim of our research consists in argumentation of the possibility of transformation of slag from potential pollutants into a new material used and its promotion as an alternative raw material for the production of consumable layers of asphalt concrete for highway.

Methodology. The research on the possibility of using the slag of the electric furnace in "Ferronickel Foundery" is based on the practice of CISRO and "Sumitomo Metals Industri" in Japan, while the products of this process, in accordance with the standards EN12697-1:2006, EN12697-23, EN12697-12, EN 12697-27 dhe DD226-26/2004, have been used as aggregates for the production of asphalt concrete in the AHN Group-Kosovo.

Findings. This paper presents the results from a study program related to minimizing the pollution impact of Fe-Ni slag landfill in Drenas, through valorization and improvement of physical-mechanical properties of slag according to the method of "integrated dry granulation" and using it afterwards as aggregate for the production of AC11 surf.

Originality. Laboratory analyses were conducted in specialized laboratory and data presented are achieved through the use of devices and equipment that are necessary for experimental research, thus the obtained results are original data presented in this paper.

Practical value. From the research data it has been proved that the conversion of Fe-Ni slag from wastes with high pollutant potentials into aggregates valuable for industry would express significant economic and environmental effects.

Keywords: EF slag, waste, dry granulation, environmental protection, asphalt pavement

Introduction. Metallurgical slag is intermediate by-product of metallurgical processes, which has been created through a variety of technical-technological processes, and with its processing can be transformed into important aggregates for widespread use in the industry. Most of the world industries, in terms of production and processing of these intermediate products are at a high level of development [1-3]. In fact, despite this, environmentally irresponsible industries, especially those in Kosovo for reason of lack of program for the management and utilization of industrial waste, are continuing with the practices of uncontrolled deposit of waste and metallurgical intermediate products in landfills. Lack of the possibility of exploitation and management of slag deposits in the Foundry of "Ferronikeli" in Drenas, has resulted in increasing concentrations of polluting components in surrounding areas.

In addition to this the increasing generation of other wastes, especially those of polymer origin and spent tires, it can be concluded that Kosovo is facing major challenges in terms of environmental protection and in general a sustainable economic development [1, 4].

Research developed in terms of opportunities to use of slag verifies that the application of the integrated dry granulation method will transform it into a resource with corrected qualities (composition and properties - by adjusting it in the valuable aggregate for cement products, asphalt concrete and all others of the construction industry). In renewable energy source, it is done through returning it in production process and reducing its pollution impacts. According to UNICEF during 2012, iron and steel production was one of the major sources of anthropogenic $\mathrm{CO}_{2}$ emissions. In the $\mathrm{EU}$, the sector is responsible for $4.7 \%$ of the total emissions, which amounts to a total of 182 million tons of $\mathrm{CO}_{2}$. The climate change externality has recently been included in the cost structure of products produced within the EU through the EU Emission Trading System [1, 5].

The latest Adoption of the Paris Agreement claimed the global response to the climate change by keeping the temperature increase below $2{ }^{\circ} \mathrm{C}$. To this end, a significant reduction in

(C) Izet Ibrahimi, Nurten Deva, Skender Muqolli, 2021 carbon dioxide emission is required, potentially resulting in more stringent emission standard on industries. As one of the most energy-and carbon-intensive industries, iron and steel manufacturing faces more grand challenge and thus has great motivation to develop and implement low carbon emission technologies [2].

A key part of this study program is the argumentation of technological possibilities for the transformation of metallurgical slag from waste with a high concentration of potential pollutants into valuable resources for the construction industry. According to the actual ferronickel production scheme, slag is discharged from the electrical furnace periodically, and through special channels it undergoes the process of granulation with water. In addition, the cooling process under the influence of water turbidity enables rapid crystallization and fractional fine-grained construction with weak bonding properties and a granulometric curve unsuitable for industrial application $[3,4,6]$. According to such practices, granular slag constitutes the main pollutants of air, water and the human environment, in general. In this case, in addition to environmental concerns, there will also be degradation of the physical-mechanical properties of slag (thus minimizing its applicability in industry), and an enormous increase in production costs and those for the management of industrial waste landfill. In order to improve the environmental situation and the level of discharge of pollutants into the atmosphere to be in line with the legal requirements for the level of pollution, "integrated dry granulation" of slag is one of the methods that would result in pollution reduction, improvement of physicalmechanical properties of the slag as well as would increase the degree of its applicability.

Processing of electric furnace slag according to the new approach has shown advanced value, not only of physical-mechanical properties, but also in terms of reactions between slag aggregates and other aggregates of bituminous mixture - AC. Results from laboratory examinations for consumables type layers AC11s with slag participatory has shown advanced feature value in terms of stability, roughness, flexibility, water absorption, plasticity, efficiency of use of bitumen, durability of road construction, and so on. 
The aim of our research consists in argumentation of the possibility of transformation of slag from potential pollutants into a new material used and its promotion as an alternative raw material for the production of consumable layers of asphalt concrete for highway.

Research methodology. Until recently, the metallurgical industries, over $35 \%$, realized all their slag production through the wet method, while recently there has been an advancement of slag processing methods and thus the increase in their applicability in the industry. Steel slag aggregate has been used in asphalt mixtures since the early 1970 s in Canada $[1,7] .10 \%$ of steel slag has been used in sinter plants in Turkey. $90 \%$ of steel slags have been inactive waiting in the slag storing yards for utilization [4].

Based on the methods for processing slag according to the "dry granulation" method and minimizing environmental pollution, we explored the possibilities of using its aggregates for the production of $\mathrm{AC} \mathrm{11s} \mathrm{as} \mathrm{a} \mathrm{layer} \mathrm{of} \mathrm{asphalt} \mathrm{concrete} \mathrm{for}$ highways. These research studies and Preparation of the Preliminary Mixture-Recipe AC 11s and other indicators, on the basis of which the study program was developed, have been carried out based on Fig. 1.

Materials and research methods for PPM - Recipe A + C 11s:

1. Filler materials - "Bajani" - Skopje/Macedonia.

2. Aggregates; $8-11.2 \mathrm{~mm}$ dhe $8 / 16 \mathrm{~mm}$ - electric furnace slag for the production of Fe-Ni- "Ferronikel Foundry" Drenas/Kosovo.

3. Fractions and sub-fractions of mineral aggregate $0 / 2$ and 2/4 mm - "Jarinje">/Leposavic/Kosovo.

4. Bitumi B50/70.

Research methods: EN 13108-20:2006/AC:2008, EN13398, EN-933, EN-12697-12, EN-12697-22, EN-12697-24, etj.

Experimental design. The Marshall Test Method was used to prepare compacted specimens, which were used to carry out tests and characterization of asphaltic concrete for AC11 mixture type. The EF slag samples from "Ferronickel Foundry" were classified as $11.2-16 \mathrm{~mm}, 8-11.2 \mathrm{~mm}, 4-8 \mathrm{~mm}$ and
2-4 mm. The chemical analysis and physical properties such as resistance to water action, to weathering, to abrasion, flatness index, specific gravity and water absorption of these slags were tested at the factory for the production of concrete asphalt, AH-Gruop Fushe Kosovo/Kosovo.

The specific gravity, stability, voids, density of bitumen, void in mineral aggregate, optimum bitumen ratios, penetration and flow characteristics were measured in AHN-Group Laboratories.

Properties of electric furnace slag in "Ferronickel Foundry" in Drenas/Kosovo. The process of smelting nickel oxide ores is a slag process, as $75 \%$ of the charge passes into slag $[1,3,5]$. Electric furnace slag is a very important component of the ferronickel production process, which requires a complete analysis. Its main physical-mechanical properties depend on its chemical composition, formation temperature and solidification method. This slag has a very complex chemical structure, where its main components are: $\mathrm{SiO}_{2}, \mathrm{CaO}, \mathrm{MgO}, \mathrm{FeO}$, $\mathrm{Fe}_{2} \mathrm{O}_{3}, \mathrm{MnO}, \mathrm{P}_{2} \mathrm{O}_{5}, \mathrm{Cr}_{2} \mathrm{O}_{3}, \mathrm{CaS}, \mathrm{MnS}, \mathrm{FeS}$, as well as nonferrous metals (Table 1) [1,3].

Research in the field of production of $\mathrm{Fe}-\mathrm{Ni}$ slag, confirms that with partial modifications it is possible to process them as slag; granular with water, crystalline, foamy and granular dry. The properties of slag are dependent on the ratio of $\mathrm{SiO}_{2}$ oxides to $\mathrm{CaO}$ and $\mathrm{MgO}$. The characteristics of slags are dependent on the ratio of $\mathrm{SiO}_{2}$ oxides to $\mathrm{CaO}$ and $\mathrm{MgO}$. Such high concentrations of $\mathrm{SiO}_{2}$ make it more suitable for application in asphalt concrete. Fig. 2 shows the "Ferronickel Foundry" electric furnace slag concentration, such as concentration of $\mathrm{SiO}_{2}, \mathrm{CaO}, \mathrm{MgO}$ and other components.

However, research studies related to this issue have proven that Ferronickel acidic slag possesses weak bonding features, but that is significantly improved by adding $\mathrm{CaO}$ (up to $25 \%$ ), Portland cement $(10-15 \%)$ and gypsum in certain proportions. There are substantial environmental and economic benefits from using nickel slag in road construction. Because nickel slag is a molten coproduct of ferronickel production, its use in highway construction reduces the need to use natural materials and results in less exploitation of natural aggregate

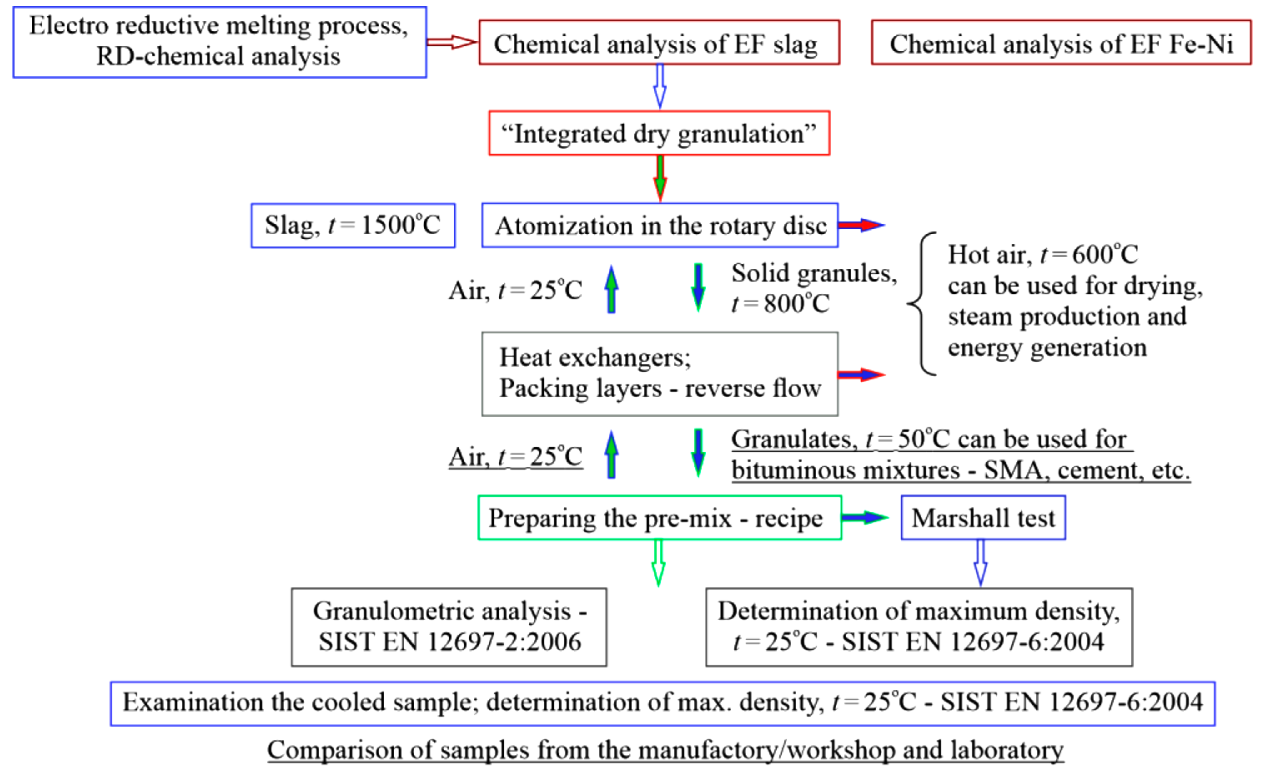

Fig. 1. Flowchart for the research methodology

Slag average chemical composition of the electric furnace [1, 3]

\begin{tabular}{|c|c|c|c|c|c|c|c|c|}
\hline Content & $\mathrm{MgO}$ & $\mathrm{SiO}_{2}$ & $\mathrm{CaO}$ & $\mathrm{Cr}_{2} \mathrm{O}_{3}$ & $\mathrm{MnO}$ & $\mathrm{Fe}$ & $\mathrm{Co}$ & $\mathrm{Ni}$ \\
\hline Quantity, $\%$ & 9.34 & 58.51 & 9.72 & 1.25 & 0.404 & 13.77 & 0.016 & 0.094 \\
\hline
\end{tabular}




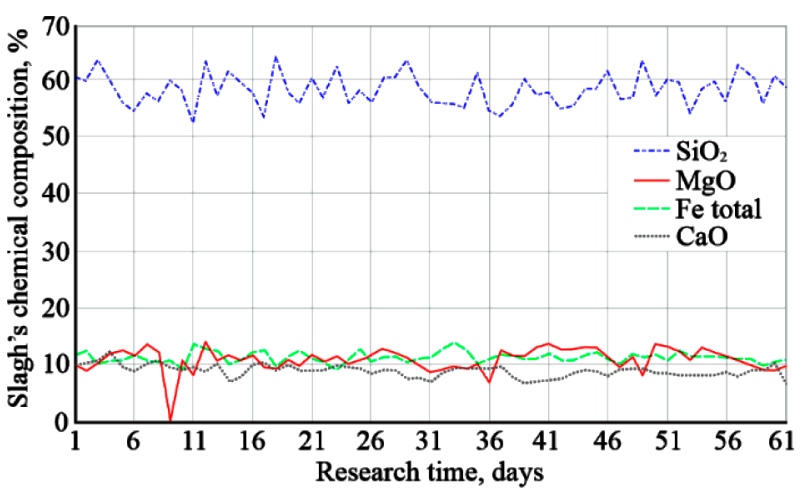

Fig. 2. Concentration of the main components in the electric furnaces slag in Drenas

deposits. Use of nickel slag also reduces the need for its disposal and lowers the cost of producing new aggregate materials $[1,8]$. Low proportion of irregularly shaped granules and lack of clay pellets will increase the quality and rates of equivalent slag fractions. These two properties enable them to have low water absorption, high compressive strength and other physi- cal-mechanical properties in accordance with the standards for silicate aggregates used in asphalt concrete, Table 2 (Source: Laboratory for asphalt "B \& A \& M" Maribor, Tomasicevo 36).

When considering the fact that EF slag is formed through a process that is associated with high liquid temperature, they, in such conditions, show a high degree of reactivity, physicalmechanical properties and chemical composition approximate or even better than the "eruptive" materials, which are used for concrete asphalt $[3,6,9]$.

Preparation of the Preliminary Mixture - Recipe.

In accordance with SIST EN 12697-1:2006, after granulometric analysis (Table 4).

Table 5 shows PPM-Recipes prepared only with slag aggregates, only those of eruptive as well as one combined with slag and eruptive aggregates. PPM-Recipe was made (for 5 types of SMA mixtures).

The determination of the percentage of bitumen, filler and mineral mixture of AC11s, was realized through the separation of the participating fractions with the system "Infra Test Asphaltanalizator", Fig 3.

The ferronickel slag of the electric furnace is characterized by low basicity, with $\mathrm{CaO} / \mathrm{SiO}_{2}$ ratio lower than 1.25 , and un-

Table 2

Research properties of Feronickel slag in "Ferronickel Foundry” Drenas/Kosovo

\begin{tabular}{|c|c|c|c|}
\hline Research & $\begin{array}{l}\text { Research method by } \\
\text { SK-EN }\end{array}$ & Research results & $\begin{array}{l}\text { Condition for quality under stand. } \\
\text { SK-EN }\end{array}$ \\
\hline Specific measures in fresh condition $\left(\mathrm{g} / \mathrm{cm}^{3}\right)$ & $12697-6$ & 2.77 & $2000-3000$ \\
\hline Specific measures in dry condition $\left(\mathrm{g} / \mathrm{cm}^{3}\right)$ & $12697-6$ & 2.69 & $2000-3000$ \\
\hline Receiving water $(\%)$ for $f=(0 / 2 \mathrm{~mm})$ & $12697-8$ & 1.07 & Is not described \\
\hline Volume measures in friable condition $\left(\mathrm{g} / \mathrm{m}^{3}\right)$ & $12697-6$ & 1.4932 & Is not described \\
\hline Volume measures in compressed condition $\left(\mathrm{g} / \mathrm{m}^{3}\right)$ & $12697-6$ & 1.5871 & Is not described \\
\hline \multirow[t]{2}{*}{ Pressure solidity (MPa) } & in dry condition & 239 & $\min .160 .80$ \\
\hline & in fresh condition & 224 & $\min .128 .64$ \\
\hline \multicolumn{2}{|l|}{ Pellet of clay (\%) } & 0 & $\begin{array}{l}<4 \mathrm{~mm} 0.5 \\
>4 \mathrm{~mm} 0.25\end{array}$ \\
\hline \multicolumn{2}{|l|}{ Composition of organic matter (\%) } & Does not contain & Is not described \\
\hline \multicolumn{2}{|l|}{ Equivalent fractions } & $12697-1$ & $\begin{array}{l}\min .60 \text { the crushed } \\
\min .70 \text { natural }\end{array}$ \\
\hline \multicolumn{2}{|l|}{$\begin{array}{l}\text { Equivalent fractions }<0.063 \mathrm{~mm} \\
\text { Equivalent fractions }<0.09 \mathrm{~mm}\end{array}$} & $12697-1$ & $\begin{aligned} & <5 \% \text { natural } \\
< & 10 \% \text { the crushed }\end{aligned}$ \\
\hline
\end{tabular}

Table 3

Table 4

Basic materials for the design of bituminous mixture AC 11E

\begin{tabular}{|c|c|c|c|}
\hline Materials & $\begin{array}{l}\text { Fraction } \\
(\mathrm{mm})\end{array}$ & $\begin{array}{c}\text { The origin of the } \\
\text { material }\end{array}$ & $\begin{array}{c}\text { Research } \\
\text { method }\end{array}$ \\
\hline Filer & - & Macedonia & $\begin{array}{l}\text { EN (933-1, } \\
1097-4)\end{array}$ \\
\hline Bitumi & BIT- 45 & $\begin{array}{l}\text { ARMO SHA } \\
\text { U.P.N. } \\
\text { Fier/Albania }\end{array}$ & $\begin{array}{l}\text { EN(1426, } \\
1427,1259)\end{array}$ \\
\hline $\begin{array}{l}\text { Quarry } \\
\text { finesse }\end{array}$ & $0 / 2$ & Jarine-Kosovo & \multirow{5}{*}{$\begin{array}{l}\text { EN (933-1, } \\
1097-2), \text { EN } \\
1097-6\end{array}$} \\
\hline Sands & $2 / 4$ & Jarine-Kosovo & \\
\hline EF slag & $4 / 8$ & $\begin{array}{l}\text { Ferronickel } \\
\text { Foundry }\end{array}$ & \\
\hline EF slag & $8 / 11.2$ & $\begin{array}{l}\text { Ferronickel } \\
\text { Foundry }\end{array}$ & \\
\hline EF slag & $11.2 / 16$ & $\begin{array}{l}\text { Ferronickel } \\
\text { Foundry }\end{array}$ & \\
\hline
\end{tabular}

Granulometric Analysis for PPM-Recipe AC 11; SIST 12697-2:2006

\begin{tabular}{|c|c|c|c|c|}
\hline $\begin{array}{c}\text { The size of } \\
\text { the sieve } \\
\text { holes }(\mathrm{mm})\end{array}$ & $\begin{array}{c}\text { The remaining } \\
\text { fractions in the sieve } \\
(\mathrm{g})\end{array}$ & $\begin{array}{c}\text { In } \\
\%\end{array}$ & Fractions & $\begin{array}{c}\text { Passing } \\
\text { in total, } \\
(\%)\end{array}$ \\
\hline $0.00-0.09$ & $37+140.4$ & 10.8 & Feller & 10.8 \\
\hline $0.09-0.25$ & 65.7 & 4 & Sands & 14.8 \\
\hline $0.25-0.71$ & 164.3 & 10 & & 24.8 \\
\hline $0.71-2$ & 49.3 & 3.0 & & 27.8 \\
\hline $2-4$ & 492.8 & 30 & \multirow{2}{*}{ EF slag } & 57.8 \\
\hline $4-8$ & 657.1 & 40 & & 97.8 \\
\hline $8-11.2$ & 36.1 & 2.2 & & - \\
\hline $11.2-16$ & - & - & & - \\
\hline $16-22.4$ & - & - & & - \\
\hline Summary: & 1642.7 & - & & 100.00 \\
\hline
\end{tabular}


Design of sample series composition for type AC 11 s B50/70

\begin{tabular}{|l|c|c|c|c|c|c|c|c|c|}
\hline \multirow{2}{*}{ Basic materials } & \multicolumn{9}{c|}{ Mineral mixture (\%) } \\
\cline { 2 - 12 } & PM 1 & PM 2 & PM 3 & PM 4 & PM 5 & PM 6 & PM 7 & PM 8 & PM 9 \\
\hline Filler/Fractions & 8.2 & 7.8 & 7.2 & 6.5 & 7.5 & 6.7 & 8.5 & 8.0 & 9.2 \\
\hline 0/2 mm, Jarinja & 5 & 5 & 5 & 36 & 36 & 36.3 & 36 & 36.5 & 35.8 \\
\hline EF slag - 0/2 mm Foundry Drenas & 31 & 31 & 31 & - & - & - & - & - & - \\
\hline 2/4 mm, Jarinja & 17 & 17 & 17 & - & - & - & 18 & 18 & - \\
\hline EF slag - 2/4 mm Foundry Drenas & - & - & - & 17 & 18 & 18 & - & - & 17 \\
\hline 4/8 mm, Jarinja & 13 & 13 & 13 & - & - & - & 14 & 13 & - \\
\hline EF slag - 4/8 mm Foundry Drenas & - & - & - & 13 & 14 & 13 & - & - & 13 \\
\hline 8/11.2 mm, Jarinja & 21.3 & 20.7 & 20.8 & - & - & - & 21 & 20 & - \\
\hline EF slag - 8/11.2 mm Foundry Drenas & - & - & - & 21 & 20 & 20 & - & - & 20 \\
\hline Bitumi B50/70 - Fier SH.P.K “ARMO” & 4.5 & 5.5 & 6.0 & 6.5 & 5.5 & 6.0 & 5.5 & 5.0 & 5.6 \\
\hline
\end{tabular}

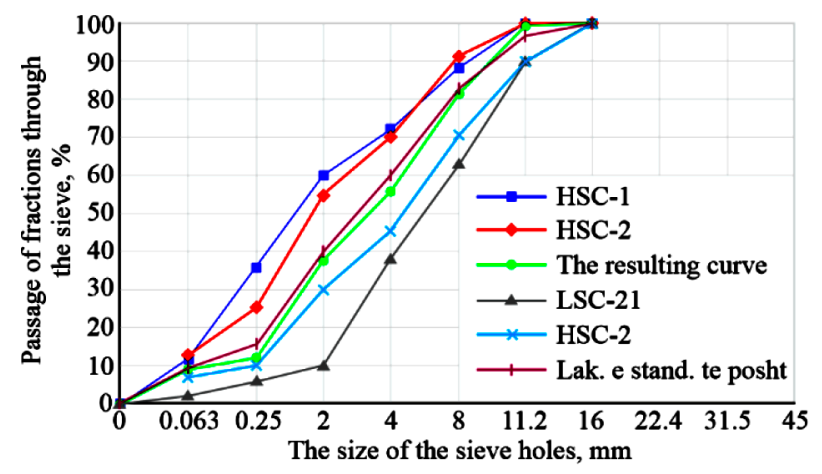

Fig. 3. Granulometric area of the pre-designed mixture of type $A C-11 \mathrm{~s}$ der the influence of the additional amount of bitumen, are formed asphalt concrete mixtures with advanced physicalchemical properties.

Discussion of results. Within a year "Ferronickel Foundry" processes over 1 million tons of $\mathrm{Ni}$ oxide ore, of which over $75 \%$ passes into slag. This slag represents the by-product from the metal smelting process, with the high value effects in economy and environment. At NewCo "Ferronickel Foundry" in Drenas/Kosovo produced slag is thrown in the landfill without adequate proper treatment. Such exploiting concepts, without any valorization strategy, have resulted in no effective manufacturing cost, irrational use of resources and high concentrations of polluting components. Volume of over 3 million $\mathrm{m}^{3}$ of deposits of this slag being under exposure to precipitation and wind has appeared highly skilled in emissions and thus is turned into permanent environmental pollutants. So the slag

Table 6

Results from the examination of other mechanical and physical properties of B50/70 AC11s type based of EF slag

\begin{tabular}{|c|c|c|c|c|c|c|c|c|c|c|}
\hline Type of processing & \multicolumn{5}{|c|}{$\mathrm{AC} 11$ surf $\mathrm{B} 50 / 70 \mathrm{~A} 3$} & \multicolumn{5}{|c|}{$\mathrm{AB} 11$ surf B50/70 A3 (andesite + slag) } \\
\hline Research method & \multicolumn{10}{|c|}{ Bitumen properties EN 1426, 1427} \\
\hline Nr. mixed. AC & PA1 & PA2 & PA3 & PA4 & PA5 & PA1 & PA2 & PA3 & PA4 & PA5 \\
\hline \multirow[t]{2}{*}{ Bitumen, $\%(\mathrm{~m} / \mathrm{m})$} & \multicolumn{10}{|c|}{ Required standard 5.5-7.5 (\%) } \\
\hline & 4.5 & 5.0 & 5.5 & 6.0 & 6.5 & 4.5 & 5.0 & 5.5 & 6.0 & 6.8 \\
\hline Bitumen density, $\left(\mathrm{kg} / \mathrm{m}^{3}\right)$ & 1020 & 1020 & 1020 & 1020 & 1020 & 1016 & 1016 & 1016 & 1016 & 1016 \\
\hline Filler, $\%(\mathrm{~m} / \mathrm{m})$ & - & - & - & - & - & 5.9 & 8.0 & 7.4 & - & 8.2 \\
\hline Research method & \multicolumn{10}{|c|}{ Test Marshall EN 12697-34; Compression temp. $\left(150 \pm 3^{\circ} \mathrm{C}\right)-2 \cdot 50$ stroke } \\
\hline \multirow[t]{2}{*}{ Stability, (kN) } & \multicolumn{10}{|c|}{ Required standard $\min .8 .0(\mathrm{KN})$} \\
\hline & 11.0 & 11.5 & 11.2 & 10.6 & 9.6 & 11.0 & 12.6 & 15.3 & 11.2 & 7.7 \\
\hline \multirow[t]{2}{*}{ Fluency, (mm) } & \multicolumn{10}{|c|}{ Required standard 2-4 (mm) } \\
\hline & 2.9 & 3.1 & 3.03 & 4.3 & 5.1 & 2.0 & 1.9 & 3.8 & 3.7 & 4.1 \\
\hline \multirow[t]{2}{*}{ Coefficient of stiff, (KN/mm) } & \multicolumn{10}{|c|}{ Required standard $<2.20(\mathrm{KN} / \mathrm{mm})$} \\
\hline & 3.8 & 3.7 & 3.6 & 2.5 & 3.5 & 5.5 & 6.5 & 4.05 & 3.02 & 1.9 \\
\hline Max. density of asph, $\left(\mathrm{kg} / \mathrm{m}^{3}\right)$ & 2493 & 2500 & 2456 & 2438 & 2427 & 2468 & 2465 & 2425 & 2455 & 2438 \\
\hline Density mixed with miner., $\left(\mathrm{kg} / \mathrm{m}^{3}\right)$ & 2305 & 2324 & 2353 & 2348 & 2324 & 2182 & 2232 & 2288 & 2353 & 2245 \\
\hline \multirow[t]{2}{*}{ Gaps, \% (v/v) } & \multicolumn{10}{|c|}{ Required standard $4.5-5.5 \%(\mathrm{v} / \mathrm{v})$} \\
\hline & 7.5 & 7.04 & 4.2 & 3.7 & 4.3 & 11.6 & 9.4 & 5.6 & 3.7 & 8.2 \\
\hline \multirow[t]{2}{*}{ Filling the gaps with bitumen, $\%(\mathrm{v} / \mathrm{v})$} & \multicolumn{10}{|c|}{ Required standard $66-78 \%(\mathrm{v} / \mathrm{v})$} \\
\hline & 57.6 & 61.2 & 75.1 & 78.9 & 81.0 & 45.5 & 46.2 & 68.9 & 79.0 & 64.4 \\
\hline Gaps in min. Mixture, $\%$ (v/v) & 17.7 & 18.4 & 16.9 & 17.5 & 18.4 & 21.3 & 20.4 & 18.0 & 17.6 & 23.3 \\
\hline Aggregate volume & 82.3 & 81.6 & 83.1 & 82.5 & 81.6 & 78.7 & 79.6 & 82.0 & 82.4 & 76.7 \\
\hline
\end{tabular}


landfill has become an environmental hotspot, because this is commonly water-cooled and has many polluting components, including extremely fine fractions or "fly ash" that fly through the air.

Some of the new technologies of steel production in their technological schemes have integrated the "dry granulation" of slag. This method has resulted in favor of energy conservation, which is considered a very important factor of this process. Apart from this, water granulation consumes large volumes of water (1000-1500 l of evaporative loss per ton of molten slag processed) and may generate acid mist causing air pollution. More importantly, the wet processing of EF slag at "Ferronickel Foundry" does not recover the large amount of high-grade heat contained in the molten slag. On cooling from around $1500{ }^{\circ} \mathrm{C}$ to ambient temperature, one ton of molten slag releases about $1.8 \mathrm{GJ}$ of heat. This could amount up to 1.4 million GJ of heat globally from electric furnace slags. Integrated dry granulation of slag in addition to energy recovery, it will transform slag from a hazardous waste into a resource with corrected qualities (composition and properties - by adjusting it in the valuable aggregate for cement products, asphalt concrete and all other of the construction industry). This energy could be utilized through the return to process, which would serve for drying, oxidation-reduction or other technological processes. Calculated for the total quantities of slag production, the research on the possibility of heat recovery would be a valuable energy potential and at the same time a contribution to the reduction of heat emissions from the greenhouse effect.

The products of the process by this method are glass slag for the production of cements, asphalt concrete or other industrial products, and at the same time the energy stored in the middle of hot air from $600{ }^{\circ} \mathrm{C}$. According to this approach, molten slag with a temperature of $1500{ }^{\circ} \mathrm{C}$ is atomized under the influence of centrifugal forces, which is manifested by the rotation of the disc to form the pellet. The pellet is then cooled and hardened under the influence of air at temperature of $23{ }^{\circ} \mathrm{C}$, which, by passing through the layer of pellets, heats air up to $600{ }^{\circ} \mathrm{C}$ and can be restored as a source of energy.

From the results of the chemical, physical-mechanical and granular analysis, the slag processed according to the dry method, or in the best cases according to the method of "integrated dry granulation", features a very homogeneous structure and low concentrations of fine fractions or "dust flight". It has maximum equivalent (100\%), no particles of clay origin, or harmful organic compounds.

Slag processed according to such a method ranks in the group of silicate materials with high concentrations of $\mathrm{SiO}_{2}$, where acidity coefficient in some cases ranges up to 4.5 , which means that these slags have high viscosity and high melting temperature, thus, enabling them to be valuable aggregates for the production of asphalt concrete.

Minimal concentrations of "fly ash", clay particles and harmful organic and inorganic compounds make it environmentally-friendly.

The regular shape of the grains requires a minimum amount of filler concentrations with limestone origin, and, in addition, such qualities of slag will improve efficiency, and will also improve other physical-mechanical properties, as well as stimulate interaction reactions between components of mixtures. Such slag compositions would also contribute to the decline of plasticity, increasing gaps in mineral, and, above all, have minimized the possibility of presenting to tight layers expansions, thereby increasing the quality and longevity of asphalt concrete.

According to the mix strength tests, it results in the fact that sample AC11s from the slag aggregates of electric furnace has increased compressive strength, high resistance to wear due to friction, good resistance to polishing, auto-tracks, and so on.

Conclusions. Processing of EF slag according to the "integrated dry granulation" at the "Ferronickel Foundry", in ad- dition to being a good opportunity of valorization of this industrial by-product, through this processing concept would make it possible to reduce the level of environmental pollution and will enable a modern management of the industrial waste landfill, which, according to the actual concept of maintenance and management, is the hottest environmental hotspot in Kosovo. This method will express important effects in relation to:

- rational use of raw materials;

- improving the physical-mechanical characteristics of products, through increasing mechanical strength, fire resistance, energy conservation, climatic resistance, and so on;

- minimizing the concentration of water steam, $\mathrm{SO}, \mathrm{SO}_{2}$, NOX, $\mathrm{CO}_{2}, \mathrm{CO}$, and other gases that would affect the greenhouse effect;

- would create the technological possibilities of converting slag from a waste with a high concentration of pollutant components into an industrially valuable aggregate;

- would also serve for the development of programs for modern landfill management, reuse and recycling of slag and other industrial waste;

- would enable the return of slag energy in the process, where in addition to environmental effects, it would express high effects in cost reduction and quality control of the product.

Application of this slag as an additional material for the production of asphalt will express more significant effects on improving the physical and mechanical characteristics of asphalt, through increased stability, stiff coefficient, surface quality, durability against deforming, climatic conditions and other chemical-mechanical effects and modification of existing technologies, and so on.

In addition to strong economic and environmental stimuli, increasing the applicability of slag would also be a contribution to the development of an environmentally conscious industry.

Acknowledgements. As authors of this paper, we thank the AHN Laboratory personnel and all other people involved in this project, for their support and assistance in the successful completion of this study. Also, we express deep respect and special thanks for your editorial office staff for providing this cooperation opportunity to publish this paper.

\section{References}

1. Ibrahimi, I., M. Rizaj, M., \& N. Deva, N. (2011). Feronikel Slag Effect In Improvement Characteristics of Surface Layer Asphalet Concrete. Materials Recycling, Silicon Photovoltaic Cells, Boron \& Borates, (4), 335-345. http://flogen.com/FraySymposium/paper-4-67.html. 2. Wang, H., Wu, J.-J., Zhu, X., Liao, Q., \& Zhao, L. (2016). Energy-environment-economy evaluations of commercial scale systems for blast furnace slag treatment: Dry slag granulation vs. water quenching. Applied Energy, 171, 314-324. https://doi.org/10.1016/j.apenergy.2016.03.079.

3. Ibrahimi, I., Deva, N., Rizaj, M., O’Brien, E.Z., \& Kongoli, F. (2017). Impact of the ferronickel slag in improvement of the construction materials properties. Sustainable Industrial Processing Summit SIPS, 7, 205. ISBN: 978-1-987820-73-7.

4. Kara, M., Günay, E., Kavakli, B., Tayfur, S., Eren, K., \& Karadag, G. (2004). The Use of Steel Slag in Asphaltic Mixture. Key Engineering Materials, 264-268, 2493-2496. https://doi.org/10.4028/www. scientific.net/kem.264-268.2493.

5. Morfeldt, J., Nijs, W., \& Silveira, S. (2015). The impact of climate targets on future steel production - an analysis based on a global energy system model. Journal of Cleaner Production, 103, 469-482. https://doi.org/10.1016/i.jclepro.2014.04.045.

6. Ibrahimi, I., Deva, N. \& Mehmeti, S. (2020). Optimalization of the Ferronickel Production Process through Improving Desulfurization Effectiveness. Civil Engineering Journal, 6(5), 907-918. https:// doi.org/10.28991/cej-2020-03091516.

7. Jahanshahi, S., \& Xie, D. (2012). Current status and future direction of CSIRO's dry slag granulation process with waste heat recovery. International Congress on the Science and Technology of Steelmaking, 1-3. 8. Wang, G., Russell G., Thompson, R., \& Wang, E. (2011). Hot-mix asphalt that contains nickel slag aggregate: Laboratory evaluation of 
use in highway construction. Transportation research record, 2208(1), 1-8. https://doi.org/10.3141/2208-01.

9. Bell, S., Davis, B., Javaid, A., \& Essadiqi, E. (2006). Final Report on Refining Technologies of Steel. Technical Report. No. 2004-21 (CF). Retrieved from https://www.researchgate.net/publication/306293435.

\section{Інтегроване сухе гранулювання - можливість зниження забруднення довкілля та валоризації шлаку $\mathrm{Fe}-\mathrm{Ni}$}

\section{Ізет Ібрахімі ${ }^{1}$, Нуртен Дева ${ }^{1}$, Скендер Муколлі ${ }^{2}$}

1 - Університет «Іса Болетіні», м. Мітровіца, Косово, email: nurten.deva@umib.net

2 - Лабораторія «AHN Груп», м. Приштина, Косово

Мета. Метою нашого дослідження є аргументація можливості трансформації шлаку із потенційних забруднюючих речовин у новий матеріал для використання його в якості альтернативної сировини для виробництва витратних шарів асфальтобетону для автомобільних доріг.

Методика. Дослідження можливості використання шлаку електропечі у «Ферронікель ФАУНДЕР» засноване на практиці компаній CISRO i «Sumitomo Metals Industri» в Японії, при цьому продукти цього процесу, відповідно до стандартів, EN12697-1:2006, EN12697-23, EN12697-12, EN 12697-27 dhe DD226-26 /2004, викорис- товувалися в якості заповнювачів для виробництва асфальтобетону в «AНN Груп-Косово».

Результати. У даній роботі представлені результати дослідницької програми, пов'язаної з мінімізацією дії забруднення, викликаного звалищем шлаків $\mathrm{Fe}-\mathrm{Ni}$ у Дренасі, за допомогою валоризації й поліпшення фізико-механічних властивостей шлаку відповідно до методу «інтегрованого сухого гранулювання» та подальшого його використання в якості заповнювача для виробництва асфальтобетону АC11.

Наукова новизна. Лабораторні аналізи проводилися у спеціалізованій лабораторії, і представлені дані отримані шляхом використання приладів і обладнання, необхідних для експериментального дослідження, таким чином, отримані результати являють собою нові дані, представлені у цій роботі.

Практична значимість. На підставі даних досліджень було доведено, що перетворення шлаку $\mathrm{Fe}-\mathrm{Ni}$ із відходів з високим потенціалом забруднення в наповнювачі, цінні для промисловості, матиме значні результати у плані економіки та екології.

Ключові слова: шлак електропечі, відходи, сухе гранулювання, охорона навколишнього середовища, асфальтове покриття

Recommended for publication by Dr. Muharrem Zabeli. The manuscript was submitted 21.10.20. 